\title{
is Research Square \\ Spatial analysis of healthy environment components in Hashtpar city, Iran
}

Habibollah Fasihi ( $\nabla$ fasihi@khu.ac.ir)

Kharazmi University

Hassan Kamran dastjerdi

University of Tehran

Farshid Sohbati Harehdasht

Kharazmi University

\section{Research Article}

Keywords: Health, Environment, Spatial distribution, Iran

Posted Date: March 3rd, 2022

DOI: https://doi.org/10.21203/rs.3.rs-1396242/v1

License: (1) This work is licensed under a Creative Commons Attribution 4.0 International License.

Read Full License 


\section{Abstract}

The environment in which we live greatly affects our health. This paper aimed to analyze the environmental factors influencing health in Hashtpar, a medium sized city with a population of about 53000 people, located in coastal plain of northern Iran. 14 indicators were included in the dataset and it is used one or a combination of 2 or more methods to generate a mean value for any of the indicators in any of the supposed 34 data collection points. The data entered into Arc Map 10.8 (GIS), then, zoning maps were produced using the Kriging interpolation tool in GIS. Findings show that generally, healthy environment indicators are higher than average level and the indicators are in better condition in central parts of the city than those in outskirts.

\section{Introduction}

The environment plays a crucial role in people's physical, mental and social well-being. Every one of us is sustained by various kinds of environmental resources such as food, materials, and energy that are harvested or otherwise extracted from the environment. Our need for those resources is absolute and we cannot survive without them.

Although the environment sustains human life, it can also influence the health of a population. The environment in which we live greatly affects our health. The interaction between human health and the environment has been extensively studied and environmental risks have been proven to significantly impact human health, either directly by exposing people to harmful agents, or indirectly, by disrupting lifesustaining ecosystems (WHO, 2009). Many factors combine together to affect the health of individuals and communities. Whether people are healthy or not, is determined by their circumstances and environment. To a large extent, factors such as where we live, the state of our environment...have considerable impacts on health, whereas the more commonly considered factors such as access and use of health care services often have less of an impact (WHO, 2014 ${ }^{\mathrm{a}}$ ).

The environment affects our health in a variety of ways. The household, workplace and outdoor environments can pose many health hazards from contamination of the air we breathe, the water we drink and the food we eat, to the risk of accidental injury from vehicles or unsafe housing. (Cairncross et al., 2008 P. 7, cited in: WHO, 2014 ${ }^{\mathrm{a}}$ ). Up to one-fifth of the total disease burden in developing countries may be associated with environmental risk factors (Irish Aid 8, 2008). A global assessment by WHO in 2016 estimated that $24 \%$ of the global disease burden and $23 \%$ of all deaths were attributed to modifiable environmental factors, including physical, chemical, and biological hazards to human health (Prüss-Ustün et al., 2016 cited in: Joubert et al., 2020). In 2012, an estimated 12.6 million deaths globally were attributable to the environment, 23 per cent of all deaths worldwide (Mc Glade et al., 2016).

Humans share an interactive relationship with the environment. Biological, physical, chemical, biomechanical, and psychosocial factors in the environment affect humans, who in turn exert an impact 
on the environment. Potentially, this interactive relationship exposes humans to environmental health hazards. These include any environmental situation or factor that can lead to disease, injury, or death.

Air pollution is the world's largest single environmental risk to health. Some 7 million people across the world die each year as a result of everyday exposure to poor air quality (Greater London Authority, 2013). In urban areas, most air pollution comes from human-made sources. Such sources can be classified as either mobile (cars, trucks, air planes, marine engines, etc.) or point source factories, electric power plants, etc.). Road traffic constitutes the major source of air pollution (Pénard-Morand and Annesi-Maesano, 2004, P. 109).

Another environmental risk to health is waterborne diseases that cause 1.5 million deaths every year (WHO 2014 ). More than half of that burden, or 842000 deaths per year, are attributable to unsafe water supply and lack of sanitation and hygiene. Surface water flooding describes flooding on the land surface from sewers, drains, groundwater and runoff from land after a heavy rainfall event. Its events are difficult to predict, but can cause significant disruptions to local populations and to health and other services (Surface Water Management Plan, 2010). Groundwaters all around the world are increasingly affected by salinization, pollution from nitrates, organic micropollutants and trace elements (Chapman, 1992). In many cities, groundwaters are used for washing and even for drinking.

Solid waste generally has a high content of organic material, thus providing breeding grounds for microorganisms and disease-bearing insects. The organization and environmental behavior of waste removal is problematic in the way that the individual incentive for disposing of waste in a sanitary way is limited.

Motorized vehicles constitute environmental problems in as much as they contribute to traffic accidents, air and noise pollution and in this way, they are a risk to human health. Road-traffic accidents are the most important cause of unintentional injury. Regarding air pollution, the emissions from transport are released close to the ground where human exposure is higher, and these may, just as indoor air pollutants, have a disproportionately high impact on human health (KjellÈn, 2001: 28). Furthermore, in urban areas, the largest source of noise is traffic-induced noise, which accounts for $80 \%$ of all communal noise sources. Traffic noise caused by road traffic is the most common type of noise in urban areas and as such poses a serious health problem (Sanja Grubesa, and Suhanek, 2020).

Settlements adjacent to farms and gardens can also be in risk from unintentional spraying. Pesticides may also affect water supplies. The major threat posed by pesticides in developing countries is acute poisoning, estimated at 3 million severe incidents per year, with some 220,000 deaths (Hogstedt and Pieris, 2000).

Although, some rivers run across cities, provide attractive landscape and recreational services, they can affect the health of users or people living near them. Along rivers, animals such as dogs, cats, mice, and snakes may be encountered and insects such as flies, mosquitoes, bees, tarantulas, scorpions are usually more abundant than places far from rivers (McCabe, 2011). Surface water pollution can however be a direct means of disease transmission for people working in or near the water. In many rivers, pathogens, 
decomposable organic matter, organic micropollutants, suspended solids or trace metals are becoming increasingly problematic swimmers or children playing by the shore (WHO, 2016).

Unlike the mentioned health risk factors, accessible green space has long been recognized as a wider environmental determinant of good health. Wide ranging research shows strong evidence that outdoor spaces have a beneficial impact on both physical and mental well-being (Greater London Authority, 2013).

Environmental issues, some of them mentioned, affect our health and have been one of the most significant triggers in the increasing awareness of the need for better environmental management. This paper aimed to investigate environmental health indicators and spatial inequality of environmental health in Hashtpar city, Iran. Due to several reasons, investigating the subject in the study area is important. The first is the diversity of geographical factors thorough out the city with an area of only less than 1380 ha: a river flowing across the city, a main crowded regional transportation axis crossing it, and the city is surrounded by farms, gardens and forests. The second one is unplanned growth of the city in recent decades that cause to appear informal settlements in part of the city, and the third reason relates to its climate. In Caspian coastal lands of Iran, warm or temperate and humid climate, high population density and paddy fields and gardens, have caused an abundance of insects, animals and disease carriers that threaten human health.

\section{Material And Methods}

14 indicators were included in the dataset of the study to assess the state of environmental health factors (table 1). To collect data, using a cross-network, 34 data collection points with approximately equal distances from each other (about $600 \mathrm{~m}$ ) were considered. At each point, we used one or a combination of 2 or more of the following methods to generate a mean value for any of the indicators: The lived experience, the opinions of 5 experts living near the point or through surveying or observing. The Values could be generated in the range between 1 and 10 which represent the worst and the best state of the indicators respectively. The coordinates of the points were obtained by using a GPS tool and the data and their relative coordinates, were set in an Excel spreadsheet and entered into Arc Map 10.8 (GIS). Then, zoning maps were produced using the Kiriging interpolation tool in GIS.

The study area (Hashtpar city) located in a coastal plain land with an average distance of $5 \mathrm{~km}$ from Caspian Sea in Iran. The city area is about 1378 hectares and it has 54178 inhabitants (Iranian Statistic Center, 2016) (Fig.1). Hashtpar is a regional transportation center and a central city in a big agricultural area with a high population density. This region is also one of the major ecotourism regions of Iran. A main road crossing the city connects thousands of villages, towns and cities of Gilan and Ardabil provinces to Rasht (the central city of Gilan province) and to Tehran (Iran the capital) and other regions of Iran.

\section{Findings}


The mean values for all the 14 indicators of healthy environment in the study area, is 6.05 , which means that generally, the state scored higher than the average of healthy environment level (5). The scores for the indicators of access to safe water, exposure to pesticides and access to green space are much higher than those for other indicators and show that environmental health in these components is more favorable than others. The most unfavorable components, the average of which is lower than the mean value include waste management, exposure to noise pollution, cleanness of the outdoor spaces and access to sewage network services respectively (table 1 ).

Table 1. The mean value of the health environment indicators

\begin{tabular}{|lll|}
\hline Rank & Index & Mean value \\
\hline 1 & Access to safe water & 9.94 \\
\hline 2 & Exposure to pesticides & 8.06 \\
\hline 4 & Access to green space & 7.15 \\
\hline 5 & Not being at the risk of being bitten and injured by insects and animals & 6.32 \\
\hline 6 & Active life facilities & 6.12 \\
\hline 7 & Exposure to air pollution & 6.06 \\
\hline 8 & Security & 5.74 \\
\hline 9 & Access to park & 5.41 \\
\hline 10 & Safety of outdoor spaces & 5.12 \\
\hline 11 & Access to sewage network & 5.05 \\
\hline 12 & Waste management & 4.94 \\
\hline 13 & Exposure to outdoor noise & 4.91 \\
\hline 14 & Cleanness of outdoor spaces & 4.82 \\
\hline
\end{tabular}

In the dry land of Iran, where the average annual rainfall is less than $250 \mathrm{~mm}$, the coastal lands of the north of the country, with an average rainfall of more than $1100 \mathrm{~mm}$ are an exception. The conditions contributed to creating rich surface and groundwater resources and providing safe clean water for most cities and villages. In the studied city, almost all residents benefit from a safe urban water network.

The north coastal plain of Iran is also an important agricultural hub and all its cities and villages are surrounded by farms and gardens. Unfortunately, farms have been sprayed indiscriminately so that in 
previous years, the amount of pesticide consumption in the Iranian northern provinces was $4 \mathrm{~kg}$ and in other Iranian provinces was only $0.7 \mathrm{~kg}$ per hectare (Nezami etal., 2010). People living on the fringes of these farms are at risk of ccontinuous spraying of farms and gardens.

These coastal lands are also among the greenest areas of Iran. The relatively low price of urban lands and urban sprawl have caused a high proportion of the cities' surface to be covered by trees and plants. In addition to being surrounded by forests, gardens and farms, about $9 \%$ of Hashtpar is covered by green space (Hashtpar Municipality, 2021). Therefore, the relative value indicates a favorable condition of healthy environment. The abundance of green spaces in and around the city and a mild climate on most days of the year also contribute to the beauty of outdoor spaces, that along with a few other factors such as smooth surface of passages, relatively high safety, lack of congestion in most passages, short distance between homes and commercial and service centers etc., promoting physical activities in the community.

In contrast, among healthy environment indicators, the cleanliness of outdoor spaces lies in lowest level. Unclean urban spaces are originally derived from poor waste management. In the study area, waste management is solely a duty and responsibility of municipality. The municipality has stationed waste skips in every neighborhood and the wastes are collected regularly, usually nightly at certain hours. Currently, households place their waste bags in front of their houses or in waste skips nearby. Warm/temperate and humid weather in summer and winter months have also caused an abundance of pets and other stray animals which contribute hugely to the garbage dispersal, in addition to swarm of insects which may serve as disease vectors. It is inevitable that in such climate, wastes would decay rapidly and its odor and leachate may pollute the surrounding environment (Fasihi et al., 2021). Littering is one of the serious social issues in environmental behavior in Iranian society and usually, domestic tourists are more likely to behave as such (Firoozjaeian et al., 2015, P. 130). Therefore, tourist cities, including the study area, are more exposed to this behavior. Litter adversely affects the environment. Be it littering along the sidewalks, on the streets or any other public urban spaces eventually pollutes environments.

Nowadays, automobile transport is the largest source of pollution of the environment in the urbanized territories. It is admitted that the noise from road traffic flows constitutes the largest danger to human health, as road transport is the source of noise located directly near the places of human residence (Mavrin et al., 2018, P. 514). A score of 4.82 means that noise pollution is a serious problem. Crossing a high congestion transit road through the city that in addition to light cars, thousands of trucks and heavy vehicles moved in it every day, is the main cause of noise and air pollution in the city. It must be added the moveable salesmen who call customers using loudspeakers mounted on light trucks.

Many parts of the city are not yet covered by the sewage network, and run off from homes and other places enters streams along passages, which can cause environmental pollution and endanger health. The index scored close to 5 . 
Generally, in the center of the city, healthy environment indicators are more favorable than those in new construction settlements located in the outer edges (Fig.2). Maps 1,4,2,5 and 3 show spatial distribution of the indicators of access to green space, cleanness of outdoor spaces, access to park, waste management and access to sewage network services respectively. These maps are very similar to the map15 that shows spatial distribution of all indicators. In other words, above indicators also have a higher score in the central neighborhoods than that in the outskirts. Spatial correlation coefficient between the both are $0.75,0.70,0.62$ and 0.61 respectively (Table 2 ), indicating a strong direct relation.

Maps 7 and 10 show a distribution almost opposite to map 15 (the mean of all indices). The three indicators of exposure to outdoor noise, security, and active life facilities are in better situation in outskirt than that in central parts of Hashtar city. Hashtpar outskirts are commonly used only as residential area, and often host very few businesses, if any at all and even tourists do not enter them, but in the center, in addition to houses, it has been located shops, service centers and business places. While in the former, all households know each other, in the latter, there are a lot of strangers including passengers, tourists, truck drivers and many other peoples who do not reside in the city. Therefore, central neighborhoods, are in less secure than the outskirts. Many researchers show that in Iranian communities, unfamiliarity is directly related to the abundance of crime and social insecurity (Koonani et al., 2016). A main road goes through the city. Here, congestion of cars and especially trucks moving in this road cause high noise pollution. Also, due to the crowded sidewalks and the congestion of cars and motorcycles in the central passages, it is not possible to walk easily and enjoy benefits of being physically active.

The abundance of various insects such as mosquitoes, beetles and bees, and animals such as mice and stray animals such as dogs has made the risk of threatening these animals everywhere. However, this risk is higher along the river (Map 13).

As shown in Map 14, the eastern edge of the city is more at risk of spraying the fields.

Table 2. Spatial correlation coefficient between the indicators and the mean of total indicators 


\begin{tabular}{|lll|}
\hline Rank & Indicator & $\begin{array}{l}\text { Correlation } \\
\text { coefficient }\end{array}$ \\
\hline 1 & Access to green space & 0.75 \\
\hline 2 & Cleanness of outdoor spaces & 0.72 \\
\hline 3 & Access to park & 0.7 \\
\hline 5 & Waste management & 0.62 \\
\hline 6 & Access to sewage network services & 0.61 \\
\hline 7 & Safety of outdoor spaces & 0.38 \\
\hline 8 & Access to safe water & 0.19 \\
\hline 9 & Exposure to air pollution & 0.14 \\
\hline 10 & Exposure to pesticides & 0.09 \\
\hline 11 & $\begin{array}{l}\text { Not being at the risk of being bitten and injured by insects and } \\
\text { animals }\end{array}$ & 0.046 \\
\hline 12 & Active life facilities & 0.038 \\
\hline 13 & Security & 0.02 \\
\hline 14 & Exposure to outdoor noise & -0.01 \\
\hline
\end{tabular}

\section{Conclusions}

In Hashtpar, like other settlements located in the coastal plain of northern Iran, the factors promote good healthy environment come from natural physical environment and climatic conditions and the weaknesses led to unhealthy environment are related to resource management, poor investment in infrastructure and urban services, lifestyle and unplanned urban growth. Unlike large and many mediumsized cities in Iran, where the indicators of a healthy environment are lower in the central part of the city than newly built settlements of outskirts, in Hashtpar, as a medium-sized city, the indicators in the central parts are more favorable than its outskirts.

\section{Declarations}

\section{Author Declarations}

The authors have no conflicts of interest to declare that are relevant to the content of this article.

The authors have no financial or proprietary interests in any material discussed in this article. 
No funds, grants, or other support was received.

Human Ethics, Animal Ethics or Plant Ethics: Not applicable

Consent for publication: Not applicable

Availability of data and materials: Data available on request from the authors

Authors' contributions: First author conceived and designed the analysis and wrote the paper. Second author: Contributed data or analysis tools and performed the analysis. Third author: Collected the data.

Acknowledgements: Thanks to Hashtpar Municipality for providing us with some data

\section{References}

1. Chapman, D., (ed.) (1992) Water Quality Assessments: A Guide to the use of biota, sediments and water in environmental monitoring. London, Chapman \& Hal

2. Damalas, C.A., . Eleftherohorinos, I.G., 2011, Pesticide exposure, safety issues, and risk assessment indicators, Published online 2011 May 6. doi: 10.3390/ijerph8051402

3. Fasihi, H., Parizadi, T., 2021, Analyzing household's environmental behavior on solid waste management and its relations with population and housing characteristics (The case:Amlash city, Iran), Journal of Environmental Management 292 (2021) 112686. https://doi.org/10.1016/j.jenvman.2021.112686

4. Firoozjaeian, A., Gholamrezazadeh, F., 2015, Pathological analysis of tourists' environmental behavior with emphasis on lithering, Quarterly Journal of Social Institution, 2(6): 128- 151 (In Persian).

5. Greater London Authority, 2013, Better environment, better health, Greater London Authority City Hall, www.london.gov.uk

6. Hogstedt, C., Pieris, B., 2000, Occupational safety and health in developing countries, Review of Strategies, Case studies and a bibliography, Arbets-livsrapport 2000:17. Arbetslivsinstitutet. National Institute for Working Life (Stockholm).

7. Iranian Statistic Center, 2016, Public Census of Population and Hosing, The shapefile from Hashtpar city (In Persian).

8. Irish Aid (8), 2008, Environment and health, Available in: www.irishaid.gov.ie bitstream/10665/150112/1/9789241564823_eng.pdf?ua=1/\&ua=1, Accessed: July 9, 2021.

9. Joubert BR, Mantooth SN and McAllister KA, 2020, Environmental health research in Africa: Important progress and promising opportunities. Front. Genet. 10:1166. doi: 10.3389/fgene.2019.01166

10. KjellÈn, Marianne, 2001, Health and environment, Swedish International Development Cooperation Agency. 
11. Knight, C., 2021, Environmental health hazards: An overview https://www.newsmedical.net/health/Environmental-Health-Hazards-An-Overview.aspx

12. Koonani, S., Mehrabi, M., 2016, Social security, The First National Conference on Futurology, Humanities and Social Security, Khorramabad, Iran: https://civilica.com/doc/667829 (In Persian).

13. Mavrin, V., Makarova, I., Prikhodko, A., 2018, Assessment of the influence of the noise level of road transport on the state of the environment, Transportation Research Procedia, Volume 36 : 514-519: https://doi.org/10.1016/j.trpro.2018.12.138

14. Nezami, Sh., Saber-e Maash, N., Safari., H., 2010, Investigating the effects of chemical pesticides used in Gilan paddy fields on the quality of water and aquatic resources, The first annual conference on water resources management in Iran, Retrieved 2 June 2021 from:

http://www.tpbin.com/article/38514 (In Persian).

15. McCabe, D. J., 2011, Rivers and streams: life in flowing water. Nature Education Knowledge 3(10):19

16. Mc Glade, J., Camila Neira, M., Ferreira de Souza, D., Payet, B., 2016, Rolph, healthy environment, healthy people: Thematic report, Ministerial Policy Review Session, https://www.researchgate.net/publication/305985822

17. Pénard-Morand, C., Annesi-Maesano, I., 2004, Air pollution: from sources of emissions to health effects, 2004, Breathe. Vol. 1, No 2. Available in: https://breathe.ersjournals.com

18. -Sanja Grubesa, S., Suhanek, M., 2020, Traffic noise, in: Noise and Environment DOI: 10.5772/intechopen.92892. Available in: https://www.intechopen.com/chapters/72522, Accessed: July, 21, 2021

19. Surface Water Management Plan, 2010, Taken from, Technical Guidance. DEFRA www.defra.gov.uk

20. World Health Organization, 2009, Preventing disease through healthy environments: Towards an estimate of the environmental burden of disease. Available online: http://www.who.int/quantifying_ehimpacts/publications/preventingdisease/en/index.html. Cited in: Remoundou, K., Koundouri, P., 2009, Environmental effects on public health: An economic perspective, Int J Environ Res Public Health, 6(8): 2160-2178. Published online 2009 Jul 31. doi: 10.3390/ijerph6082160

21. World Health Organization, 2014 ${ }^{a}$, The determinants of health [cited http://www.who.int/hia/evidence/doh/en, Accessed July 9, 2021.

22. World Health Organization, $2014^{\mathrm{b}}$, Preventing diarrhea through better water, sanitation and hygiene. Exposures and impacts in low- and middle- income countries. Geneva: WHO, http://apps.who.int/iris/

\section{Figures}



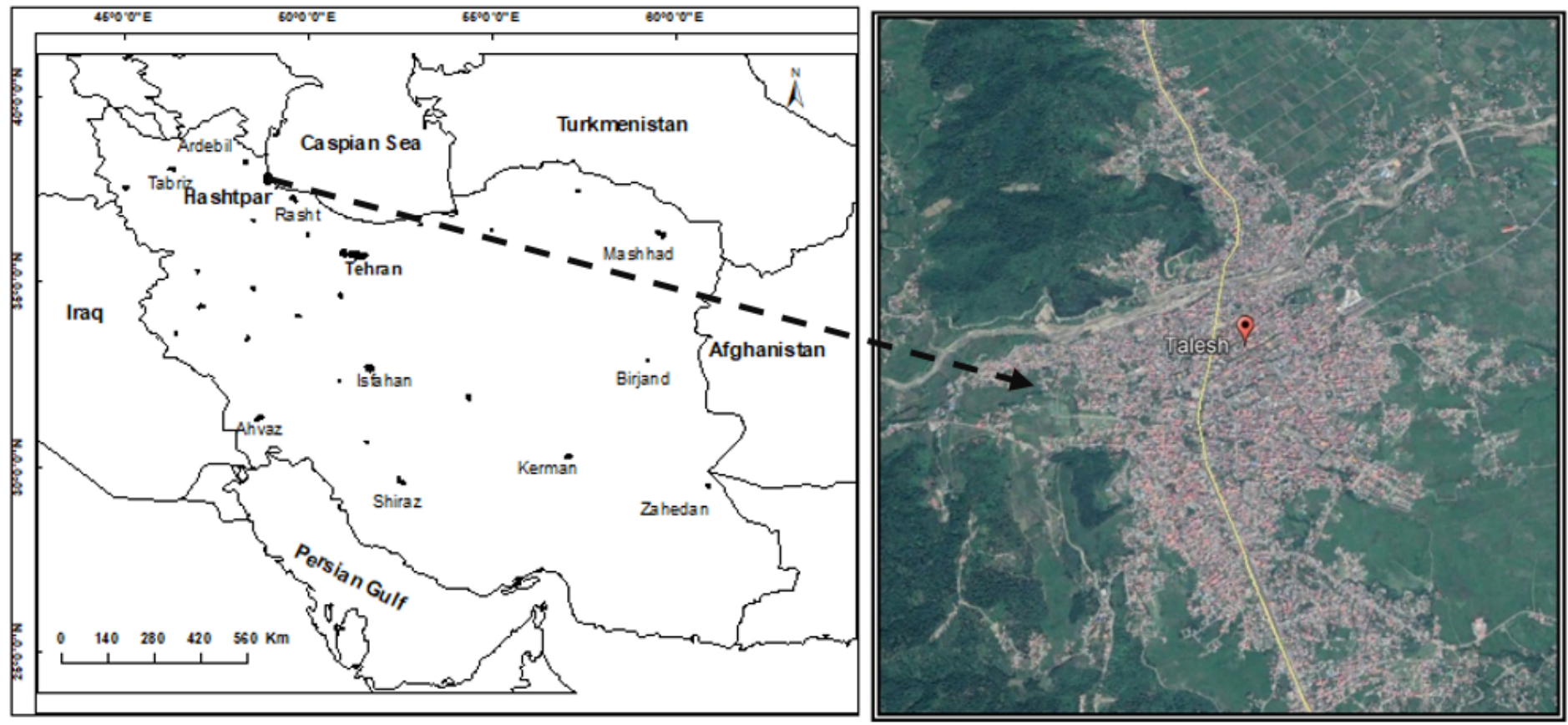

Figure 1

Location of Hashtpar city in Iran 

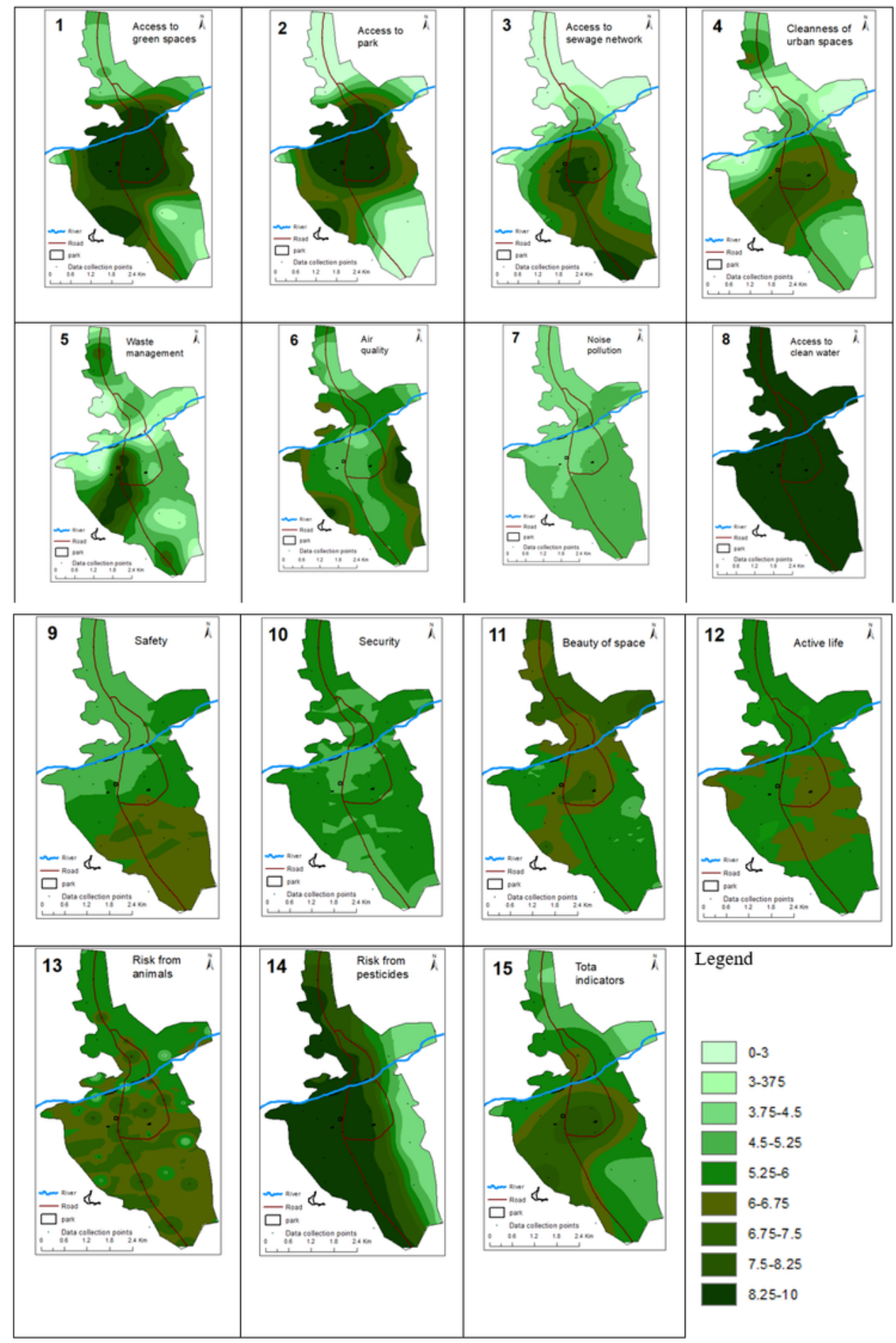

Figure 2

Spatial distribution of heathy environment indicators in Hashtpar 